\title{
Bacillus litoralis sp. nov., isolated from a tidal flat of the Yellow Sea in Korea
}

Correspondence

Jung-Hoon Yoon

jhyoon@kribb.re.kr

\author{
Jung-Hoon Yoon and Tae-Kwang Oh \\ Korea Research Institute of Bioscience and Biotechnology (KRIBB), PO Box 115, Yusong, \\ Taejon, South Korea
}

\begin{abstract}
A Gram-variable, motile, endospore-forming, slightly halophilic bacterial strain, designated SW- $211^{\top}$, was isolated from a tidal flat of the Yellow Sea in Korea, and was characterized taxonomically by using a polyphasic approach. The organism grew optimally at $37^{\circ} \mathrm{C}$ and in the presence of $2-3 \% \mathrm{NaCl}$. Comparative $16 \mathrm{~S}$ rRNA gene sequence analysis showed that strain $\mathrm{SW}-211^{\top}$ forms a distinct phylogenetic lineage within the radiation of the cluster comprising Bacillus species. Strain SW- $211^{\top}$ had cell-wall peptidoglycan based on meso-diaminopimelic acid. The predominant menaquinone was MK-7 and the major fatty acids were anteiso- $\mathrm{C}_{15: 0}$ $(34.8 \%)$, iso- $C_{15: 0}(15.6 \%)$, iso- $C_{16: 0}(12.5 \%)$ and iso- $C_{14: 0}(10.0 \%)$. The DNA G +C content was $35 \cdot 2 \mathrm{~mol} \%$. Strain SW-211 ${ }^{\top}$ exhibited levels of $16 \mathrm{~S}$ rRNA gene sequence similarity of $<96.2 \%$ with respect to the type strains of recognized Bacillus species. On the basis of its phenotypic properties and phylogenetic distinctiveness, strain SW $-211^{\top}\left(={\text { KCTC } 3898^{\top}=\mathrm{DSM}}^{\top}\right.$ $16303^{\top}$ ) was classified in the genus Bacillus as the type strain of a novel species, for which the name Bacillus litoralis sp. nov. is proposed.
\end{abstract}

Tidal sediments have been utilized as excellent sources for isolating novel and useful micro-organisms (Yi et al., 2003; Yoon et al., 2003a). Some new genera or species have recently been isolated from tidal sediments in Korea (Yi et al., 2003; Yoon et al., 2003a, b, 2004a, b). In the course of screening novel micro-organisms from a tidal flat near Daepo beach in the Yellow Sea in Korea, many moderately halophilic or halotolerant bacteria have been isolated and characterized taxonomically. Of these isolates, a rod-shaped, endospore-forming bacterial strain, $\mathrm{SW}-211^{\mathrm{T}}$, is described here. Its exact taxonomic position was determined by using a polyphasic approach that included phenotypic properties and phylogenetic analysis based on 16S rRNA gene sequences.

Strain $\mathrm{SW}-211^{\mathrm{T}}$ was isolated by a standard dilution plating technique on marine agar 2216 (MA; Difco) at $30^{\circ} \mathrm{C}$. Cell morphology was examined by light microscopy (Nikon E600) and transmission electron microscopy (TEM). Flagellum type was examined by TEM using cells from exponentially growing cultures. Gram-reaction was determined by using the bioMérieux Gram Stain kit according to the manufacturer's instructions. Growth under anaerobic conditions was determined after incubation in an anaerobic chamber on MA and on MA supplemented with nitrate,

Published online ahead of print on 13 May 2005 as DOI 10.1099/ ijs.0.63332-0.

The GenBank/EMBL/DDBJ accession number for the 16S rRNA gene sequence of strain $\mathrm{SW}-211^{\top}$ is AY608605. both of which had been prepared anaerobically using nitrogen. The $\mathrm{pH}$ range for growth was determined in marine broth 2216 (MB; Difco) that was adjusted to various $\mathrm{pH}$ values (initial $\mathrm{pH} 4 \cdot 5-9 \cdot 5$ at intervals of $0.5 \mathrm{pH}$ units). The $\mathrm{pH}$ was adjusted prior to sterilization by the addition of $\mathrm{HCl}$ or $\mathrm{Na}_{2} \mathrm{CO}_{3}$. Growth at various $\mathrm{NaCl}$ concentrations was investigated in $\mathrm{MB}$ or trypticase soy broth (Difco). Growth in the absence of $\mathrm{NaCl}$ was investigated in trypticase soy broth lacking $\mathrm{NaCl}$. Growth at various temperatures $\left(4-50^{\circ} \mathrm{C}\right)$ was measured on MA. Catalase and oxidase activities and hydrolysis of casein, gelatin, hypoxanthine, starch, Tween 80 , tyrosine and xanthine were determined as described by Cowan \& Steel (1965). Hydrolysis of aesculin and nitrate reduction were determined as described by Lanyi (1987). $\mathrm{H}_{2} \mathrm{~S}$ production was tested as described by Bruns et al. (2001). Acid production from carbohydrates was determined according to the method of Leifson (1963). Utilization of substrates as sole carbon and energy sources was tested as described by Baumann \& Baumann (1981), with the substrates supplemented with $2 \%(\mathrm{v} / \mathrm{v})$ Hutner's mineral base (Cohen-Bazire et al., 1957) and $1 \%(\mathrm{v} / \mathrm{v})$ vitamin solution (Staley, 1968). Enzyme activity was determined by using the API ZYM system (bioMérieux). Other physiological and biochemical tests were performed with the API 20E system (bioMérieux). Morphological, cultural, physiological and biochemical characteristics of strain SW$211^{\mathrm{T}}$ are shown in Table 1 or are given in the species description.

Cell biomass for DNA extraction and for cell-wall and isoprenoid quinone analyses was obtained from cultivation 
Table 1. Phenotypic characteristics of Bacillus litoralis sp. nov. and some related Bacillus species

Species: 1, B. litoralis sp. nov.; 2, B. fastidiosus (data from Claus \& Berkeley, 1986); 3, Bacillus cibi (Yoon et al., 2005); 4, Bacillus indicus (Suresh et al., 2004); 5, Bacillus horikoshii (Nielsen et al., 1995; Li et al., 2002; Logan et al., 2002); 6, Bacillus halmapalus (Nielsen et al., 1995; Li et al., 2002; Logan et al., 2002); 7, Bacillus cohnii (Spanka \& Fritze, 1993; Suresh et al., 2004); 8, Bacillus cereus (Claus \& Berkeley, 1986; Priest et al., 1988); 9, Bacillus flexus (Claus \& Berkeley, 1986; Suresh et al., 2004); 10, Bacillus megaterium (Claus \& Berkeley, 1986; Reva et al., 2002; Täubel et al., 2003); 11, Bacillus simplex (Priest et al., 1988; De Clerck et al., 2004). +, Positive; -, negative; ND, not determined; NG, no growth; V, variable. Data in parentheses are for the type strain. Cells of all species are rod-shaped and catalase-positive.

\begin{tabular}{|c|c|c|c|c|c|c|c|c|c|c|c|}
\hline Characteristic & 1 & 2 & 3 & 4 & 5 & 6 & 7 & 8 & 9 & 10 & 11 \\
\hline Spore shape ${ }^{*}$ & $\mathrm{E}$ & $\mathrm{E}$ & E & ND & $\mathrm{E}$ & $\mathrm{E}$ & E & E & $\mathrm{ND}$ & E & $\mathrm{E}$ or $\mathrm{C}$ \\
\hline Spore position $\dagger$ & $\mathrm{C}, \mathrm{S}$ or $\mathrm{T}$ & ND & $\mathrm{C}$ or $\mathrm{S}$ & S & S & $\mathrm{C}$ or $\mathrm{S}$ & $\mathrm{T}$ & $\mathrm{C}$ & ND & $\mathrm{C}$ & $\mathrm{C}, \mathrm{S}$ or $\mathrm{T}$ \\
\hline Oxidase & + & ND & + & ND & ND & ND & + & $\mathrm{V}$ & $\mathrm{ND}$ & - & - \\
\hline Anaerobic growth & - & - & - & - & - & - & ND & + & $\mathrm{ND}$ & - & - \\
\hline \multicolumn{12}{|l|}{ Growth at/in: } \\
\hline $5 \%(\mathrm{w} / \mathrm{v}) \mathrm{NaCl}$ & + & + & + & - & + & - & + & + & + & + & + \\
\hline $10 \%(\mathrm{w} / \mathrm{v}) \mathrm{NaCl}$ & + & - & + & - & - & - & - & $\mathrm{V}$ & $\mathrm{ND}$ & - & - \\
\hline $10^{\circ} \mathrm{C}$ & + & + & + & - & + & + & + & $\mathrm{V}$ & $\mathrm{ND}$ & + & $\mathrm{ND}$ \\
\hline $45^{\circ} \mathrm{C}$ & + & ND & + & - & - & - & + & ND & $\mathrm{ND}$ & ND & ND \\
\hline Nitrate reduction & - & - & - & - & - & - & + & + & - & - & + \\
\hline \multicolumn{12}{|l|}{ Hydrolysis of: } \\
\hline Aesculin & + & ND & + & + & + & + & $(-)$ & + & - & + & - \\
\hline Casein & + & - & + & $\mathrm{ND}$ & + & + & $\mathrm{v}(+)$ & + & $\mathrm{ND}$ & + & + \\
\hline Gelatin & + & - & - & + & + & + & + & + & - & + & + \\
\hline Starch & + & - & + & + & + & + & + & $\mathrm{V}$ & $\mathrm{ND}$ & + & + \\
\hline Tween 80 & + & ND & + & ND & - & - & $\mathrm{v}(+)$ & $\mathrm{V}$ & ND & ND & $\mathrm{V}$ \\
\hline \multicolumn{12}{|l|}{ Growth on: } \\
\hline D-Galactose & + & ND & + & ND & - & - & ND & ND & $\mathrm{ND}$ & $(-)$ & ND \\
\hline D-Cellobiose & + & ND & + & + & ND & ND & $(-)$ & ND & + & $(-)$ & $\mathrm{V}$ \\
\hline D-Mannose & - & ND & + & + & $\mathrm{V}$ & + & $(-)$ & ND & - & $(-)$ & - \\
\hline Sucrose & + & ND & + & + & ND & ND & $(-)$ & ND & + & $(-)$ & $\mathrm{ND}$ \\
\hline Maltose & + & ND & + & + & ND & ND & $(-)$ & ND & + & $(+)$ & - \\
\hline Pyruvate & + & ND & + & - & ND & ND & $(+)$ & ND & - & $(-)$ & ND \\
\hline \multicolumn{12}{|l|}{ Acid production from: } \\
\hline D-Glucose & + & NG & + & - & + & + & $(-)$ & + & + & + & + \\
\hline Lactose & + & ND & - & - & - & - & $(-)$ & V & - & V & - \\
\hline D-Mannitol & - & NG & - & - & + & - & $(-)$ & - & - & + & $\mathrm{V}$ \\
\hline D-Mannose & - & ND & + & + & $\mathrm{V}$ & + & $(-)$ & $\mathrm{V}$ & - & V & $\mathrm{V}$ \\
\hline D-Xylose & + & NG & - & - & V & $\mathrm{V}$ & $(-)$ & - & - & + & - \\
\hline $\begin{array}{l}\text { DNA G + C content } \\
(\mathrm{mol} \%)\end{array}$ & $35 \cdot 2$ & $\begin{array}{c}34 \cdot 3-35 \cdot 1 \\
(35 \cdot 1)\end{array}$ & 45 & $41 \cdot 2$ & $41 \cdot 1-42 \cdot 0$ & $38 \cdot 6$ & $33 \cdot 9-35 \cdot 0$ & $\begin{array}{c}31 \cdot 7-40 \cdot 1 \\
(35 \cdot 7 \text { or } 36 \cdot 2)\end{array}$ & $38 \cdot 4$ & $\begin{array}{c}36 \cdot 5-45 \cdot 0 \\
(37 \cdot 3 \text { or } 37 \cdot 6)\end{array}$ & $40-41$ \\
\hline
\end{tabular}

${ }^{\star} \mathrm{C}$, Cylindrical; E, ellipsoidal or oval.

$\dagger$, Central or paracentral; s, subterminal; T, terminal.

in $\mathrm{MB}$ at $37^{\circ} \mathrm{C}$. Chromosomal DNA was isolated and purified according to the method described by Yoon et al. (1996), with the modification that RNase T1 was used in combination with RNase A to minimize contamination with RNA. The $16 \mathrm{~S}$ rRNA gene was amplified by PCR using two universal primers as described by Yoon et al. (1998). Sequencing of the amplified 16S rRNA gene and phylogenetic analysis were performed as described by Yoon et al. (2003a). The isomer type of diamino acid of the cell-wall peptidoglycan was determined by the method of Komagata \& Suzuki (1987). Isoprenoid quinones were extracted and analysed as described by Komagata \& Suzuki (1987) using reversed-phase HPLC. For fatty acid methyl ester analysis, a loop of cell mass was harvested from MA plates after cultivation for 2 days at $37^{\circ} \mathrm{C}$. The fatty acid methyl esters were extracted and prepared according to the standard protocol of the MIDI/Hewlett Packard Microbial Identification System (Sasser, 1990). The DNA G + C content was determined by the method of Tamaoka \& Komagata (1984) with a modification that DNA was hydrolysed and the resultant nucleotides were analysed by reversed-phase HPLC. 
An almost complete 16S rRNA gene sequence of strain SW- $211^{\mathrm{T}}$ comprising $1505 \mathrm{nt}$ (approximately $96 \%$ of the Escherichia coli 16S rRNA gene sequence) was analysed. Comparative 16S rRNA gene sequence analyses showed that strain SW $-211^{\mathrm{T}}$ is phylogenetically affiliated to Bacillus species. The phylogenetic tree based on the neighbourjoining algorithm showed that strain $\mathrm{SW}-211^{\mathrm{T}}$ fell within the radiation of the cluster comprising Bacillus species and joined Bacillus fastidiosus with a bootstrap resampling value of $98.0 \%$ (Fig. 1). Strain SW-211 ${ }^{\mathrm{T}}$ exhibited $16 \mathrm{~S}$ rRNA gene sequence similarity levels of $96 \cdot 2 \%$ to the type strain of B. fastidiosus and lower than $95 \cdot 3 \%$ with respect to the type strains of other recognized Bacillus species. Sequence similarities to all other species included in the phylogenetic analysis were below $91 \cdot 4 \%$ (Fig. 1). Strain SW- $211^{\mathrm{T}}$ contained meso-diaminopimelic acid as the diagnostic diamino acid in the cell-wall peptidoglycan. The predominant isoprenoid quinone found in strain SW-211 ${ }^{\mathrm{T}}$ was unsaturated menaquinone with seven isoprene units (MK-7). Major components $(>5 \%)$ of the fatty acids detected in strain $\mathrm{SW}-211^{\mathrm{T}}$ were branched fatty acids anteiso- $\mathrm{C}_{15: 0}$ $(34 \cdot 8 \%)$, iso- $\mathrm{C}_{15: 0}(15 \cdot 6 \%)$, iso- $\mathrm{C}_{16: 0}(12 \cdot 5 \%)$, iso- $\mathrm{C}_{14: 0}$ $(10.0 \%)$ and anteiso- $\mathrm{C}_{17: 0}(6.4 \%)$ and straight-chain fatty acid $\mathrm{C}_{16: 0}(5 \cdot 5 \%)$. The DNA G $+\mathrm{C}$ content of strain $\mathrm{SW}-211^{\mathrm{T}}$ was $35 \cdot 2 \mathrm{~mol} \%$.

The results obtained from the phenotypic and phylogenetic characterizations indicated that strain $\mathrm{SW}-211^{\mathrm{T}}$ belongs to the genus Bacillus. The phylogenetic distinctiveness (16S

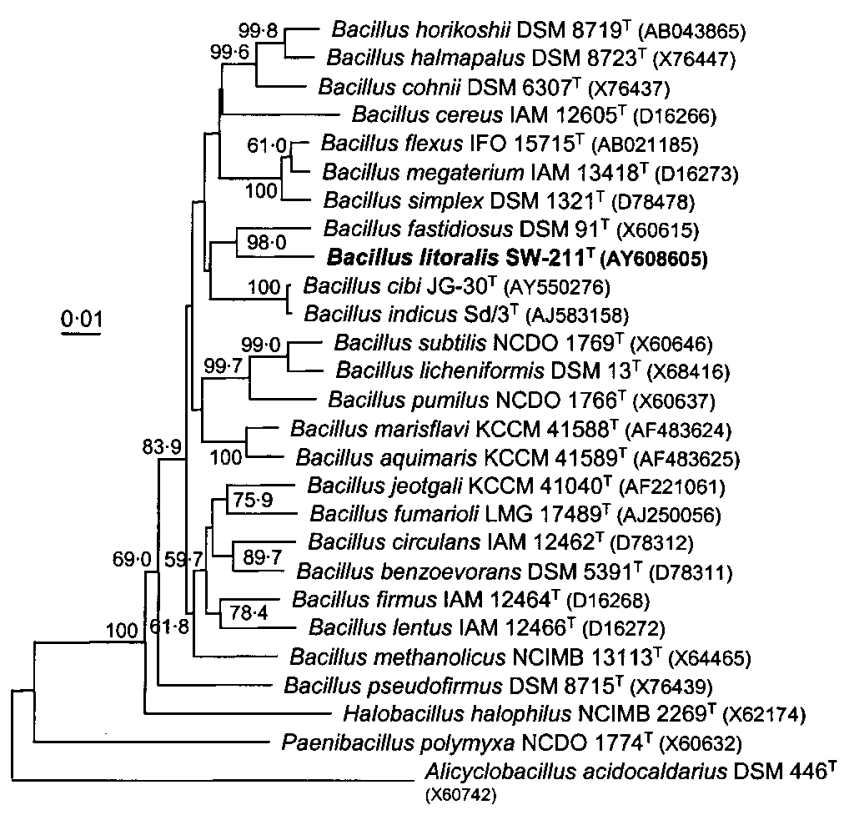

Fig. 1. Neighbour-joining tree showing the phylogenetic positions of $\mathrm{SW}-211^{\top}$, some Bacillus species and representatives of other related taxa based on 16S rRNA gene sequence analysis. Bootstrap values (expressed as percentages of 1000 replications) greater than $50 \%$ are shown at branch points. Bar, 0.01 substitutions per nucleotide position.
rRNA gene sequence similarity of $<97 \%$ ) confirms that strain SW-211 ${ }^{\mathrm{T}}$ represents a species distinct from recognized Bacillus species (Stackebrandt \& Goebel, 1994). There were some phenotypic differences between strain SW-211 ${ }^{\mathrm{T}}$ and several phylogenetically related Bacillus species (Table 1). Therefore, on the basis of the data presented, strain SW-211 ${ }^{\mathrm{T}}$ should be classified in the genus Bacillus as a member of a novel species, for which the name Bacillus litoralis sp. nov. is proposed.

\section{Description of Bacillus litoralis sp. nov.}

Bacillus litoralis (li.to.ra'lis. L. masc. adj. litoralis of the shore).

Cells are aerobic rods, $0 \cdot 8-1 \cdot 0 \times 2 \cdot 5-4 \cdot 5 \mu \mathrm{m}$ in size. Gramvariable. Motile by means of peritrichous flagella. Central, subterminal or terminal ellipsoidal endospores are observed in swollen sporangia. Colonies grown on MA are circular to slightly irregular, smooth, slightly raised, yellowish white in colour and 2-3 $\mathrm{mm}$ in diameter after 2 days of incubation at $37^{\circ} \mathrm{C}$; colony colour becomes dark from the centre as cultures age. Optimal growth temperature is $37^{\circ} \mathrm{C}$; growth occurs at 4 and $45^{\circ} \mathrm{C}$ but not above $46^{\circ} \mathrm{C}$. Optimal pH for growth is $7 \cdot 5$. Growth is observed at $\mathrm{pH} 5.5$ but not at $\mathrm{pH} 5 \cdot 0$. Optimal growth occurs in the presence of $2-3 \%$ $(w / v) \mathrm{NaCl}$; growth does not occur without $\mathrm{NaCl}$ or in the presence of $>11 \%(\mathrm{w} / \mathrm{v}) \mathrm{NaCl}$. Anaerobic growth does not occur on MA or on MA supplemented with nitrate. Catalase-positive. Urease-negative. Hypoxanthine, tyrosine and xanthine are not hydrolysed. $\mathrm{H}_{2} \mathrm{~S}$ and indole are not produced. Arginine dihydrolase, lysine decarboxylase, ornithine decarboxylase and tryptophan deaminase are absent. When assayed with the API ZYM system, alkaline phosphatase, esterase (C4), esterase lipase (C8), acid phosphatase and naphthol-AS-BI-phosphohydrolase are present, but lipase (C14), leucine arylamidase, valine arylamidase, cystine arylamidase, trypsin, $\alpha$-chymotrypsin, $\alpha$-galactosidase, $\beta$-galactosidase, $\beta$-glucuronidase, $\alpha$ glucosidase, $\beta$-glucosidase, $N$-acetyl- $\beta$-glucosaminidase, $\alpha$-mannosidase and $\alpha$-fucosidase are absent. Acid is produced from L-arabinose, D-cellobiose, D-fructose, Dgalactose, D-melezitose, melibiose, D-raffinose, L-rhamnose, D-ribose, sucrose and D-trehalose. Acid is not produced from adonitol, D-sorbitol, myo-inositol or maltose. The following substrates are utilized for growth: L-arabinose, D-fructose, D-glucose, D-trehalose, D-xylose, lactose, acetate and L-malate. Benzoate, citrate, formate, succinate or L-glutamate are not utilized. The cell-wall peptidoglycan contains meso-diaminopimelic acid. The predominant menaquinone is MK-7. The major fatty acids are anteiso$\mathrm{C}_{15: 0}(34 \cdot 8 \%)$, iso- $\mathrm{C}_{15: 0}(15 \cdot 6 \%)$, iso- $\mathrm{C}_{16: 0}(12 \cdot 5 \%)$ and iso- $\mathrm{C}_{14: 0}(10 \cdot 0 \%)$. The DNA G $+\mathrm{C}$ content is $35 \cdot 2 \mathrm{~mol} \%$ (determined by HPLC).

The type strain, SW $-211^{\mathrm{T}}\left(=\right.$ KCTC $\left.3898^{\mathrm{T}}=\mathrm{DSM} 16303^{\mathrm{T}}\right)$, was isolated from a tidal flat near Daepo beach of the Yellow Sea in Korea. 


\section{Acknowledgements}

This work was supported by the 21C Frontier programme of Microbial Genomics and Applications (grant MG02-0401-001-1$0-0)$ from the Ministry of Science and Technology (MOST) of the Republic of Korea.

\section{References}

Baumann, L. \& Baumann, P. (1981). The marine Gram-negative eubacteria; genera Photobacterium, Beneckea, Alteromonas, Pseudomonas, and Alcaligenes. In The Prokaryotes. A Handbook on Habitats, Isolation, and Identification of Bacteria, pp. 1302-1330. Edited by M. P. Starr, H. Stolp, H. G. Trüper, A. Balows \& H. G. Schlegel. Berlin: Springer.

Bruns, A., Rohde, M. \& Berthe-Corti, L. (2001). Muricauda ruestringensis gen. nov., sp. nov., a facultatively anaerobic, appendaged bacterium from German North Sea intertidal sediment. Int J Syst Evol Microbiol 51, 1997-2006.

Claus, D. \& Berkeley, R. C. W. (1986). Genus Bacillus Cohn 1872. In Bergey's Manual of Systematic Bacteriology, vol. 2, pp. 1105-1140. Edited by P. H. A. Sneath, N. S. Mair, M. E. Sharpe \& J. G. Holt. Baltimore: Williams \& Wilkins.

Cohen-Bazire, G., Sistrom, W. R. \& Stanier, R. Y. (1957). Kinetic studies of pigment synthesis by nonsulfur purple bacteria. J Cell Comp Physiol 49, 25-68.

Cowan, S. T. \& Steel, K. J. (1965). Manual for the Identification of Medical Bacteria. London: Cambridge University Press.

De Clerck, E., Rodríguez-Díaz, M., Vanhoutte, T., Heyman, J., Logan, N. A. \& De Vos, P. (2004). Anoxybacillus contaminans sp. nov. and Bacillus gelatini sp. nov., isolated from contaminated gelatin batches. Int J Syst Evol Microbiol 54, 941-946.

Komagata, K. \& Suzuki, K. (1987). Lipids and cell-wall analysis in bacterial systematics. Methods Microbiol 19, 161-207.

Lanyi, B. (1987). Classical and rapid identification methods for medically important bacteria. Methods Microbiol 19, 1-67.

Leifson, E. (1963). Determination of carbohydrate metabolism of marine bacteria. I Bacteriol 85, 1183-1184.

Li, Z., Kawamura, Y., Shida, O., Yamagata, S., Deguchi, T. \& Ezaki, T. (2002). Bacillus okuhidensis sp. nov., isolated from the Okuhida spa area of Japan. Int J Syst Evol Microbiol 52, 1205-1209.

Logan, N. A., Lebbe, L., Verhelst, A., Goris, J., Forsyth, G., Rodriguez-Diaz, M., Heyndrickx, M. \& De Vos, P. (2002). Bacillus luciferensis sp. nov., from volcanic soil on Candlemas Island, South Sandwich archipelago. Int J Syst Evol Microbiol 52, 1985-1989.

Nielsen, P., Fritze, D. \& Priest, F. G. (1995). Phenetic diversity of alkaliphilic Bacillus strains: proposal for nine new species. Microbiology 141, 1745-1761.

Priest, F. G., Goodfellow, M. \& Todd, C. (1988). A numerical classification of the genus Bacillus. J Gen Microbiol 134, 1847-1882.
Reva, O. N., Smirnov, V. V., Pettersson, B. \& Priest, F. G. (2002) Bacillus endophyticus sp. nov., isolated from inner tissues of cotton plants (Gossypium sp.). Int J Syst Evol Microbiol 52, 101-107.

Sasser, M. (1990). Identification of Bacteria by Gas Chromatography of Cellular Fatty Acids. Newark, DE: MIDI Inc.

Spanka, R. \& Fritze, D. (1993). Bacillus cohnii sp. nov., a new, obligately alkaliphilic, oval-spore-forming Bacillus species with ornithine and aspartic acid instead of diaminopimelic acid in the cell wall. Int J Syst Bacteriol 43, 150-156.

Stackebrandt, E. \& Goebel, B. M. (1994). Taxonomic note: a place for DNA-DNA reassociation and $16 \mathrm{~S}$ rRNA sequence analysis in the present species definition in bacteriology. Int J Syst Bacteriol 44, 846-849.

Staley, J. T. (1968). Prosthecomicrobium and Ancalomicrobium: new prosthecate freshwater bacteria. J Bacteriol 95, 1921-1942.

Suresh, K., Prabagaran, S. R., Sengupta, S. \& Shivaji, S. (2004) Bacillus indicus sp. nov., an arsenic-resistant bacterium isolated from an aquifer in West Bengal, India. Int J Syst Evol Microbiol 54, 1369-1375.

Tamaoka, J. \& Komagata, K. (1984). Determination of DNA base composition by reverse-phase high-performance liquid chromatography. FEMS Microbiol Lett 25, 125-128.

Täubel, M., Kämpfer, P., Buczolits, S., Lubitz, W. \& Busse, H.-J. (2003). Bacillus barbaricus sp. nov., isolated from an experimental wall painting. Int J Syst Evol Microbiol 53, 725-730.

Yi, H., Chang, Y.-H., Oh, H. W., Bae, K. S. \& Chun, J. (2003). Zooshikella ganghwensis gen. nov., sp. nov., isolated from tidal flat sediments. Int J Syst Evol Microbiol 53, 1013-1018.

Yoon, J.-H., Kim, H., Kim, S.-B., Kim, H.-J., Kim, W. Y., Lee, S. T., Goodfellow, M. \& Park, Y.-H. (1996). Identification of Saccharomonospora strains by the use of genomic DNA fragments and rRNA gene probes. Int J Syst Bacteriol 46, 502-505.

Yoon, J.-H., Lee, S. T. \& Park, Y.-H. (1998). Inter- and intraspecific phylogenetic analysis of the genus Nocardioides and related taxa based on 16S rRNA gene sequences. Int J Syst Bacteriol 48, 187-194.

Yoon, J.-H., Kim, I.-G., Kang, K. H., Oh, T.-K. \& Park, Y.-H. (2003a). Bacillus marisflavi sp. nov. and Bacillus aquimaris sp. nov., isolated from sea water of a tidal flat of the Yellow Sea in Korea. Int J Syst Evol Microbiol 53, 1297-1303.

Yoon, J.-H., Weiss, N., Kang, K. H., Oh, T.-K. \& Park, Y.-H. (2003b). Planococcus maritimus sp. nov., isolated from sea water of a tidal flat in Korea. Int J Syst Evol Microbiol 53, 2013-2017.

Yoon, J.-H., Kang, K. H., Oh, T.-K. \& Park, Y.-H. (2004a). Shewanella gaetbuli sp. nov., a slight halophile isolated from a tidal flat in Korea. Int J Syst Evol Microbiol 54, 487-491.

Yoon, J.-H., Kim, I.-G., Oh, T.-K. \& Park, Y.-H. (2004b). Microbulbifer maritimus sp. nov., isolated from an intertidal sediment from the Yellow Sea, Korea. Int J Syst Evol Microbiol 54, 1111-1116.

Yoon, J.-H., Lee, C.-H. \& Oh, T.-K. (2005). Bacillus cibi sp. nov., isolated from jeotgal, a traditional Korean fermented seafood. Int J Syst Evol Microbiol 55, 733-736. 